\begin{abstract}
Iranica
Abstracta Iranica Revue bibliographique pour le domaine irano-aryen

Volume 34-35-36 | 2017

Comptes rendus des publications de 2011-2013
\end{abstract}

\title{
Mark A. Christian. Phoenician Maritime Religion: Sailors, Goddess Worship, and the Grotta Regina
}

\section{Astrid Nunn}

\section{(2) OpenEdition}

1 Journals

\section{Édition électronique}

URL : http://journals.openedition.org/abstractairanica/41211

DOI : 10.4000/abstractairanica.41211

ISSN : 1961-960X

Éditeur :

CNRS (UMR 7528 Mondes iraniens et indiens), Éditions de l'IFRI

\section{Référence électronique}

Astrid Nunn, "Mark A. Christian. Phoenician Maritime Religion: Sailors, Goddess Worship, and the Grotta Regina », Abstracta Iranica [En ligne], Volume 34-35-36 | 2017, document 95, mis en ligne le 15 juillet 2016, consulté le 26 septembre 2020. URL : http://journals.openedition.org/abstractairanica/41211 ; DOI : https://doi.org/10.4000/abstractairanica.41211

Ce document a été généré automatiquement le 26 septembre 2020.

Tous droits réservés 


\title{
Mark A. Christian. Phoenician Maritime Religion: Sailors, Goddess Worship, and the Grotta Regina
}

\author{
Astrid Nunn
}

\section{RÉFÉRENCE}

Mark A. Christian. « Phoenician Maritime Religion: Sailors, Goddess Worship, and the Grotta Regina ». Die Welt des Orients, 43/2, 2013, p. 179-205.

1 Tanit, une " permutation » d'Astarté, était adorée dans des grottes et sur des bateaux. Ceci est valable pour toute la Méditerranée, comme le prouvent des graffitis dans la Grotta Regina située au nord de Palerme. Après analyse de matériel archéologique et de textes, l'A. conclut que son culte ne pouvait être exercé que par des marins qui avaient servi sur des bateaux marchands ou militaires. La caste phénicienne des prêtres était stationnaire dans les cités et représentée par des délégués itinérants dans les régions côtières moins densément habitées.

\section{AUTEURS}

\section{ASTRID NUNN}

Université de Munich 